\title{
Strategy for Improving the Competitiveness of Shipyards in the Eastern Part of Indonesia
}

\author{
Suandar Baso ${ }^{1)^{*}}$, Musrina $^{2)}$, Andi Dian Eka Anggriani ${ }^{1)}$ \\ 1) Department of Naval Architecture, Faculty of Engineering, Hasanuddin University, Gowa 92171, Indonesia \\ 2) PT. Diginova Elektra Multimedia, Grand Slipi Tower Building, Jl. Ledjend S. Parman, Jakarta Barat, Indonesia \\ *) Corresponding Author : s.baso@eng.unhas.ac.id
}

\section{Article Info}

Keywords:

Shipyard,

Competitiveness,

Analytical Hierarchy Process,

Blue Ocean Strategy

\section{Article history:}

Received: 10/04/20

Last revised: 13/06/20

Accepted: 17/06/20

Available online: 25/06/20

DOI:

https://doi.org/10.14710/kapal. v17i2.29448

\section{Abstract}

In recent years, the number of shipyards in Indonesia has increased significantly to anticipate the increasing demand and the government policy regarding the Cabotage Principles and Masterplan for Acceleration and Expansion of Indonesia's Economic Development (MAEIED), and three Archipelagic Sea-Lanes (ASL's) in Indonesia. However, shipbuilding and ship repair works have been centered in the western part of Indonesia. Therefore, this study aims to develop a potential strategy of shipyards in the eastern part of Indonesia to compete in the current market situation. The Analytical Hierarchy Process (AHP) method was used to model the strategy hierarchy and analyze the weight of sub-criteria as the internal and external factors of the shipyard competitiveness. Then, the Blue Ocean Strategy method was used to analyze the competitiveness strategy. To improve competitiveness, the shipbuilding industries in the eastern part of Indonesia have to focus intensively on reforming and upgrading several internal environment factors such as coordination and response, business network, high skill manpower, and complex ship types building ability. Besides, the shipyards also have to focus on external environmental factors, particularly on five factors that have a high influence on improving competitiveness, namely shipping company partners, networks and partnership with suppliers, government policies, human resource development, and cluster formation of shipyards.

Copyright (c) 2020 KAPAL : Jurnal Ilmu Pengetahuan dan Teknologi Kelautan. This is an open access article under the CC BY-SA license (https://creativecommons.org/licenses/by-sa/4.0/).

\section{Introduction}

There are three Archipelagic Sea-Lanes (ASL's) in Indonesia which enable maritime transit through Indonesia's archipelago. These lanes can be passed by international shipping [1]. As a result, these will increase some potential benefits in the maritime sector. Therefore, Indonesia government has planned alternative international hub seaports in the eastern part of Indonesia such as in Makassar and Bitung [2]. Furthermore, Indonesia government has developed the economic corridors through the program of Masterplan for Acceleration and Expansion of Indonesia' s Economic Development/MAEIED (Masterplan Percepatan dan Perluasan Pembangunan Ekonomi Indonesia/MP3EI) [2]. Indonesia' s Government has also implemented policies namely Cabotage Principle in 2005 to empower the national shipping industry.

By the implications of the ASL's, the MAEIED, and the Cabotage Principle, the shipyards in Indonesia are indeed able to anticipate the demands that are increasing significantly. The demands have been shown from the capacity for new buildings reaching up to 900,000 DWT per year. However, the shipyard's utility was only $60 \%$. The total domestic and international trade covered general cargo, container, dry bulk, and liquid bulk reached 968,361,000 tons in 2009 [3].

These conditions have a positive impact on enhancing further the role of the shipbuilding industry in the maritime economy sector. However, ship production and repair activities are generally centered in the western part of Indonesia. Therefore, the shipyards in the eastern part of Indonesia need a proper strategy to improve their competitiveness and sustainability.

Several studies have discussed related shipyard development strategies. The competitiveness of shipbuilding industry in Russia was assessed in order to analyse the current state and competitive potential [4], the China' s shipbuilding cost and its impact on the competitiveness were assessed [5], and the potential competitiveness and the dominant competitiveness of the China' s shipbuilding industry were analysed by using the diamond model and the causal analysis paradigm [6].

Study of the efficiency, productivity, growth, and stability of Korean small and medium sized shipyards were analysed by using the data envelopment analysis (DEA) model and Malmquist index in order to classify their competitiveness and uncompetitiveness [7]. Then, the strategic business of the medium-sized shipyards in Indonesia was analysed by using 
Shipyard Business matrix [8]. The Brazilian shipbuilding industry was diagnosed and then the innovation and competitiveness were analysed by de Araujo [9]. The competitiveness of Indian shipbuilding industry was summarized based on the gaps and issues [10]. The shipyard mid-term prodthe internal and external environments of Romanian Naval Industry were identified and analyzed using the SWOT model [11]. The China shipbuilding industry was analysed by using the SWOT based on third eyes [12]. All these studies have discussed some methods as well for obtaining the valuable results.

On the other hand, the studies subjected to the improvement of shipyard have been carried out by using the Analytical Hierarchy Process (AHP) such as the evaluation of shipyard selection criteria for shipowners [13], the identification and contribution of the factors on the challenges faced by the shipyard industry in Malaysia [14], the measurement of the productivity of 21 major shipyards in China, South Korea and Japan [15]. The AHP method which was used in those studies are relevant to assess the influence factors. Also, the factors that influenced shipyard performance have been discussed clearly.

Taking a different approach, a few studies regarding the use of Blue Ocean Strategy (BOS) method have been presented [16], [17], [18]. However, the BOS method was not applied to the shipyard case and it was suitably used to solve the industry problems. Nonetheless, only one study of shipyard development using the BOS method has been conducted. This study has focused on the development of the new markets of the Luxury Sailing Yacht industry through value innovation and the Blue Ocean Strategy [19].

Several methods have been applied to several studies on strategy of shipyards development, as explained above. However, the application of the Blue Ocean Strategy (BOS) method has rarely been used on the study of shipyard strategy. Meanwhile, the Analytical Hierarchy Process (AHP) method has been applied to many studies of the shipping industry.

Based on the explanation above, the present study aims to formulate a strategy for the shipyards in the eastern part of Indonesia to improve their competitiveness to compete with shipyards in the western part of Indonesia in the current market situation. The econometric analysis has been used to describe the shipyard's current market potential in the eastern part of Indonesia. For meeting and reaching the existing market potential together with future projections, the strategy has been formulated firstly by considering the criteria and sub-criteria as internal and external environmental factors that influence the shipyard's competitiveness. This study has used the combined AHP [20] and BOS [21] methods to interpret the internal and external factors, becoming a strategy for improving the competitiveness of shipyards. Systematically, the AHP method has been used to decompose a model and formulate the competitiveness factors. Meanwhile, the BOS method has been used to reconstruct the internal and external factors and formulate a competitiveness strategy after modeling using the AHP method.

\section{Methods}

In this study, the current market potential for the shipyard in the eastern part of Indonesia has been described by the analysis of the number of ship demand, the volume of vessel transport, the parameters of capacity, and the market. These obtained results have been used to investigate and understand the shipyard's existing condition and then the projection of ship volume could be made. By this overall information, a strategy for improving the competitiveness of the shipyards in the eastern part of Indonesia could be formulated by using the combined AHP and BOS method.

For modeling a strategy using AHP method, the criteria and sub-criteria as the internal and external factors which influence the shipyard improvement has been identified. Then, the weight of the sub-criteria was calculated in order to decide and order the strategy action priority based on the Likert Scale. Correspondingly, the internal and external factors were then reconstructed by using the BOS method to formulate the strategy of shipyard competitiveness.

Therefore, the methods used for resulting the parameters subjected to the market potential, the competitiveness factors and the improvement strategy for the shipyards in the eastern part of Indonesia have been explained accordingly.

\subsection{Econometric Analysis}

Initially, the output of the shipyard activities (new building and repair) was measured and then it was converted to the measurement of the Compensated Gross Tonnage (CGT). The volume of vessel transport and market potential was assessed using the compensated gross tonnage as well. The compensated gross tonnage was calculated by multiplying the gross tonnage of a ship by a coefficient according to ship type and size and the function is expressed as:

$$
\operatorname{cgt}=A g t^{B}
$$

where $A$ is the coefficient of the ship type influence, $g t$ is ship' s gross tonnage and $B$ is the coefficient of the ship size.

Similarly, the number of demands for freight services by ship type for each hinterland was predicted by using the statistical analysis of the multiple regressions where the dependent variable was the amount of charge and the independent variable consisted of four factors namely population, agricultural product, total electricity sold, and Gross Regional Domestic Product (GRDP) at the current price. Meanwhile, the type of cargo that becomes the dependent variable included containers, general cargoes, dry bulks and passengers.

For the analysis, the secondary data were collected from documentation obtained from the Central Bureau Statistics of Indonesia for annual economic information in the eastern part of Indonesia within the last five years and the Indonesia Port Corporations for current cargo and vessel data records. Data were collected from the Indonesia National Shipowners Association (INSA) and the Indonesia Shipbuilding and Offshore Industries Association (IPERINDO) that provide shipbuilding industry data in Indonesia. 
Furthermore, all calculation results that have been explained above were used for the purpose of the econometric analysis. The econometric analysis was then used to model and predict the number of ship demands in the future by using the multiple regressions' statistical analysis.

\subsection{The Formulation of the Criteria and Sub-criteria for the Competitiveness Factors}

In this part, the formulation of the criteria and sub-criteria, which influences the competitiveness on the shipyards, were explained. The identified criteria and sub-criteria were the competitiveness factors. Two ways were done for formulating the criteria and sub-criteria i.e., literature review and discussion with the expert people. All literature and published articles were searched in online databases related to shipyard improvement and competitiveness by using the following keywords: shipyard, shipbuilding, competitiveness strategy, maritime role, ship repair, shipbuilding market, and demand. Meanwhile, the criteria and sub-criteria were identified and determined in discussing with the expert people based on an open-ended question analysis subjected to internal and external environment factors of the shipyards. Moreover, the expert people were addressed to whom had a background in shipbuilding, ship design, ship production, entrepreneur, academic staff and researcher. Also, the expert people were the manager level in the shipyard company.

The targeted shipyards in the eastern part of Indonesia were addressed to the middle-class (5,000-30,000 DWT) and the small-class (less than 5,000 DWT). However, only 8 (eight) medium size shipbuilding companies were observed in this study, namely PT. IKI (Persero) Makassar, PT. Sarana Samudra Pasific Bitung, PT. Pertamina Dok Sorong Papua Barat, PT. Galangan Balikpapan Utama Balikpapan, PT. Dok Kodja Bahari Banjarmasin, PT. IKI Bitung, PT. Steadfast Marine Pontianak, and PT. Dok dan Perkapalan Waiame Ambon. This research used non-probability sampling techniques by considering the types of ship produced or repaired by the shipyard including tankers, bulk carriers, general cargo, containers and ferries.

\subsection{The Decomposition and Weight of the Criteria and Sub-criteria Using Analytical Hierarchy Process}

After formulating the criteria and sub-criteria influenced competitiveness, the criteria and sub-criteria were modeled by using Analytical Hierarchy Process (AHP) [20] without alternatives. The model contained only the objective, criteria, and sub-criteria. The objectives of the model were to decompose criteria and sub-criteria, to obtain the value and the weight of criteria and sub-criteria. The value of criteria and sub-criteria were collected by using closed-ended questions addressed to the manager level employees of shipbuilding companies as respondents. The respondent number was 24 people in eight medium-size shipbuilding companies. These were analyzed to determine the multilevel scale of criteria and sub-criteria of internal and external environmental factors. The comparison of the influence level of a factor was presented in a pairwise comparison matrix with an absolute value element, as can be seen in Table 1 . The absolute values for matrix elements are 1 , $3,5,7$, and 9 and for the interested intensity representing five elements of the Likert Scale are strongly agree, agree, neutral, disagree, and strongly disagree. By obtaining the value of criteria and sub-criteria given by some respondents, therefore the value was averaged for the next calculation on the weight of criteria and sub-criteria.

Furthermore, the weight of criteria and sub-criteria was calculated by dividing the number of rows of the normalization matrix with the total of the sum result column, as given in Table 2. For the weights of the different criteria, a pairwise comparison matrix is a real matrix based on the number of criteria or sub-criteria, for instance, a $n \times n$ matrix (A) is created, where $n$ is the number of criteria or sub-criteria. The matrix A consists of value $a_{i j}$, where $i$ is a base alternative for comparison, corresponding to row $i$, and $j$ is the alternative being compared with $i$. The important relationship in the matrix is given:

$$
a_{i j} \times a_{j i}=1
$$

The matrix $A$ is derived to the normalized pairwise comparison matrix $A_{\text {norm }}$ by making equal to 1 the sum of the entries on each column, i.e. each entry $\bar{a}_{i j}$ of the matrix $A_{\text {norm }}$ is calculated as:

$$
\bar{a}_{i j}=\frac{\bar{a}_{i j}}{\sum_{l=1}^{m} a_{l j}}
$$

Thereafter, the criteria or sub-criteria weight vector $w$ in $n$-dimensional column vector is built by averaging the entries on each row of $A_{\text {norm }}$ as given:

$$
w_{i}=\frac{\sum_{l=1}^{m} \bar{a}_{i l}}{n}
$$

The weight of sub-criteria factors was obtained by multiplying the elements weight given in the Table 2 with the weight resulted from closed-ended questions, which then depicted into the competitiveness strategy curve.

Table 1. Matrix Paired for Influence Factors

\begin{tabular}{llllll}
\hline Element & Strongly agree & Agree & Neutral & Disagree & Strongly disagree \\
\hline Strongly agree & 1 & 3 & 5 & 7 & 9 \\
Agree & 0.33 & 1 & 3 & 5 & 7 \\
Neutral & 0.20 & 0.33 & 1 & 3 & 5 \\
Disagree & 0.14 & 0.20 & 0.33 & 1 & 3 \\
Strongly disagree & 0.11 & 0.14 & 0.20 & 0.33 & 1 \\
SUM & $\mathbf{1 . 7 8 7}$ & $\mathbf{4 . 6 7 6}$ & $\mathbf{9 . 5 3 3}$ & $\mathbf{1 6 . 3 3 3}$ & $\mathbf{2 5 . 0 0 0}$ \\
\hline
\end{tabular}


Table 2. The Weight of Five Elements of The Likert Scale

\begin{tabular}{ll}
\hline Element & Weight \\
\hline Strongly agree & $0.503(100 \%)$ \\
Agree & $0.260(51.75 \%)$ \\
Neutral & $0.134(26.72 \%)$ \\
Disagree & $0.068(13.48 \%)$ \\
Strongly disagree & $0.035(6.93 \%)$ \\
\hline
\end{tabular}

Consistency Index $(\mathrm{CI})$ was obtained by calculating the scalar $x$ as the average of the elements of the vector whose $i$ th element is the ratio of the jth element of the vector $\mathrm{A} x w$ to the corresponding element of the vector $w$. This is given by:

$$
C I=\frac{x-n}{n-1}
$$

Then, the consistency of the criteria and sub-criteria values was checked by calculating the consistency ratio (CR). This consistency could be checked for each A matrix and overall model. The formula of CR is given:

$$
C R=\frac{C I}{R I}
$$

where $R I$ is random index. In this study, the value constraint of the consistency index $(\mathrm{CI})$ is given 0.061 and the value of the consistency ratio (CR) is 0.05 . The consistency ratio of smaller than $10 \%$ signifies a consistent hierarchy and accuracy.

\subsection{The Formulation of the Sub-criteria Using Blue Ocean Strategy}

For formulating the sub-criteria using BOS method, the weight of sub-criteria factors obtained from AHP method was then reconstructed by using the Eliminate-Reduce-Raise-Create Grid (ERRC Grid) of the Blue Ocean Strategy (BOS) method [21]. In order to reconstruct these values, some questions were made based on the sub-criteria and then discussed again with respondents to obtain an alternative strategy. The respondents were the manager level of the shipyards that mentioned previously (eight medium size shipbuilding companies). The number of respondents is 22 people. The discussion results described the reconstruction of the sub-criteria through the ERRC Grid after this influence level of each sub-criterion was measured where the level of influence on sub-criteria was classified into five levels as shown in Table 3.

Table 3. The Classification of The Influence Level on Sub-Criteria After Reconstructed Using BOS Method

\begin{tabular}{ll}
\hline Classified Influence Level & Weight \\
\hline No effect & $0-1.5$ \\
Low & $1.5-3$ \\
Medium & $3-6$ \\
Height & $6-11.4$ \\
Very height & $11.4-22$ \\
\hline
\end{tabular}

\section{Results and Discusion}

\subsection{Market Potential for Shipyard in the Eastern Part of Indonesia}

There are 24 shipyards in the eastern part of Indonesia, including 18 companies in Kalimantan Island, three companies in Sulawesi Island, and three companies in Maluku and Papua Islands. Based on this condition, the number of shipbuilding companies in the eastern part is small compared to those in the western part of Indonesia, even though the eastern area covered a much larger area. However, shipbuilding industry activities have been increasing and allowing the opening of new shipyards in this eastern region.

The shipping industry's potential market is strongly influenced by the total demand for the shipping services of a region. In the current condition, the volume of the ship transportation is about 5.28 million compensated gross tonnages (CGT) in Sulawesi, 2.79 million CGT in Kalimantan, and 4.32 million CGT in Papua-Maluku as shown in Table 4. The comparison between market potential used capacity and installed capacity for the ship repair market of each shipyard in the eastern part of Indonesia is shown in Figure 1. For instance, based on the shipyard capacity of PT. IKI, market share for ship repair in the regional market, has reached $4.29 \%$ while it can reach up to $35.22 \%$ in the local competition. This report shows that the market share absorption in regional is significantly lower compared to the local market.

The potential of new shipbuilding until 2019 has been predicted by the State Minister for National Development Planning/Head of National Development Planning Agency of Indonesia. Five types of vessels will be needed to meet the demand raised from the Sea Toll program, Cabotage Principles, and feeder lines including container ships 1000-3000 TEUs, general cargo 4000 DWT, dry bulk 3000-5000 DWT, tanker 2500-50000 DWT and ferry ro-ro 8000 GT with the total number of the ship was estimated up to 388 units or 107.052,88 CGT. The installed capacity of the shipyards in the eastern part of Indonesia can contribute to the domestic competition of 107.052.88 CGT. However, these target capacities have not been fully achieved yet. The market potential of new shipbuilding and installed capacity by several shipyards in the eastern part of Indonesia is shown in Figure 2. The capacity of the Bitung SSP shipyard is the only one that surpassed the potential of new building markets with actual capacity reaching 93\% for general cargo and 55\% dry bulk vessel. 
Furthermore, the number of demands for freight services by ship type for each hinterland in the future was predicted until 2025 by using multiple regressions. The dependent variable was the amount of charge and the independent variable consisted of four factors namely, population, agricultural product, total electricity sold, and Gross Regional Domestic Product (GRDP) at the current price. Meanwhile, the type of cargo that becomes the dependent variable included containers, general cargoes, dry bulks, and passengers.

\begin{tabular}{|c|c|c|c|c|}
\hline Transport type & Sulawesi & Kalimantan & Papua-Maluku & CGT \\
\hline Container & 954,003 & 366,075 & 479,790 & $1,799,867$ \\
\hline Passenger & $3,524,604$ & $2,039,821$ & $3,538,556$ & $9,102,980$ \\
\hline General Cargo & 803,493 & 386,228 & 296,780 & $1,486,501$ \\
\hline TOTAL & $5,282,099$ & $2,792,124$ & $4,315,126$ & $12,389,348$ \\
\hline
\end{tabular}

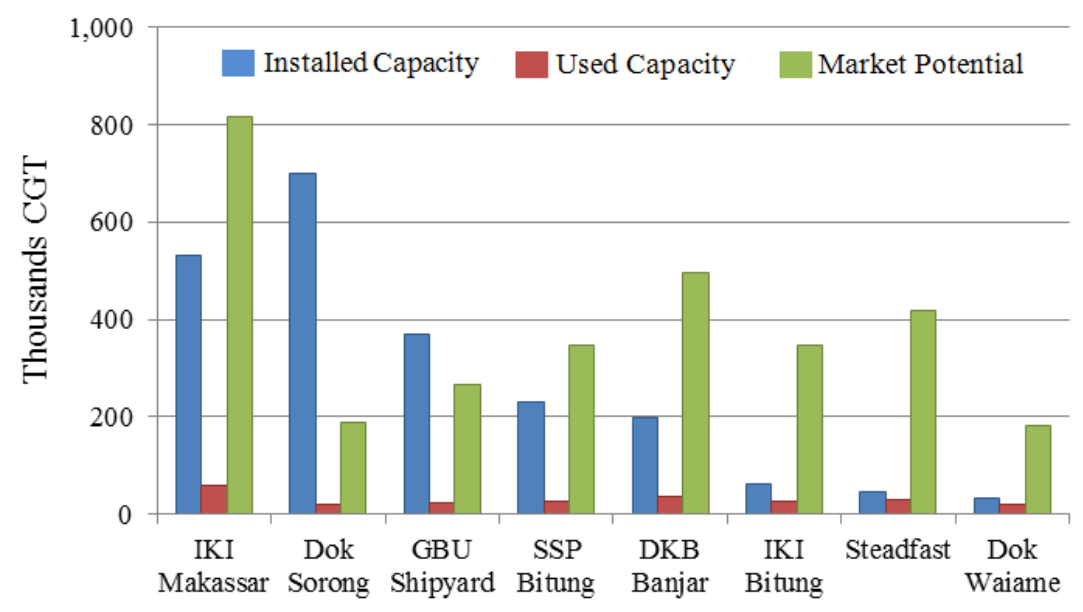

Figure 1. The Market Potential, Used Capacity, and Installed Capacity for Ship Repair Market of Shipyards in The Eastern Part of Indonesia

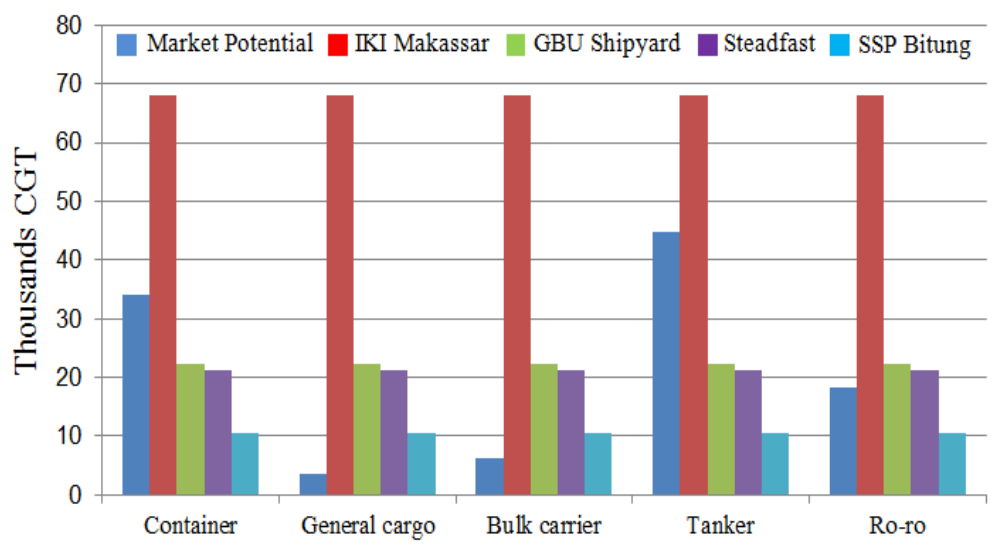

Figure 2. The Market Potential of New Shipbuilding and Installed Capacity by Several Shipyards in the Eastern Part of Indonesia

The growth of cargo vessels' type until 2025 in the eastern part of Indonesia is shown in Figure 3 to Figure 6. Makassar container terminal has started to operate and serviced up to $4.099 .653 \mathrm{ton} / \mathrm{m}^{3}$ since 2008 . Bitung container terminal commenced operation in 2011 and initially serviced 936.974 ton/m3. Balikpapan container terminal has operated firstly in 2013 and has serviced up to $1.764 .461 \mathrm{ton} / \mathrm{m}^{3}$. The demand for container transport services mostly comes from Makassar and followed by Balikpapan and Bitung, respectively, as shown in Figure 3. In addition, the demand for this service in the area of Banjarmasin, Ambon, and Sorong areas has been increasing every year.

Based on Figure 4, the potential demand for more general cargo service is around feeder routes such as Bitung and Balikpapan areas. The demand for general cargo transport in Bitung area is about 55.95\% higher than in Makassar area. Likewise, the demand for the general cargo service in Balikpapan and Banjarmasin areas is about 25 times more than in Sorong or Ambon areas. Indeed, the demand for both services in Balikpapan and Banjarmasin areas has been increasing continuously up to $5 \%$. Then, it is hoped that the implementation of trade, followed by the Sea Toll program will increase the demand for freight service around Sorong and Ambon feeder lanes. 


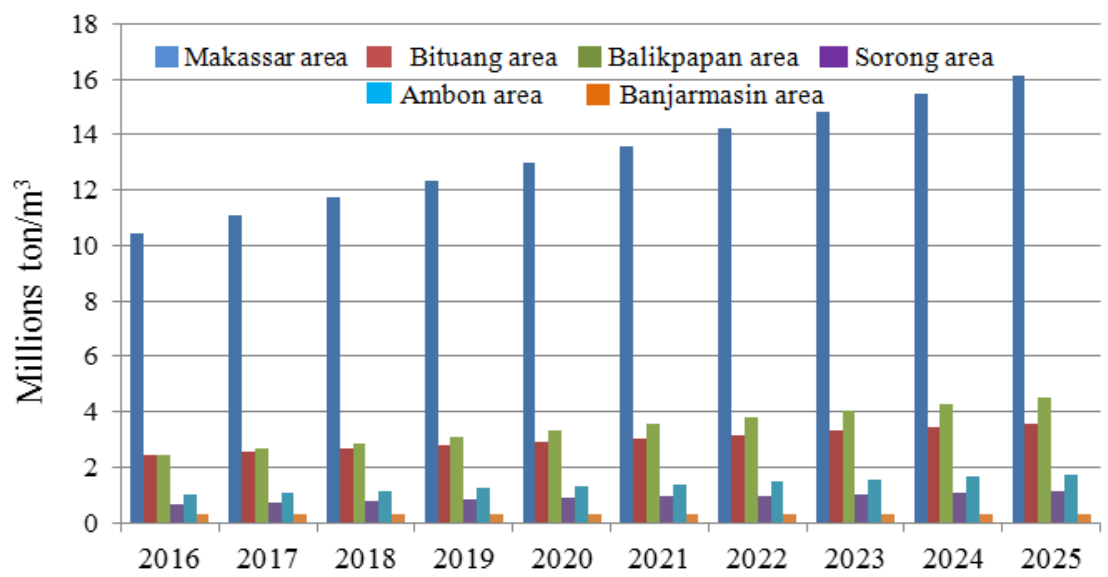

Figure 3. Projection of Demand for Container Transport Services in Hinterland of The Eastern Part of Indonesia

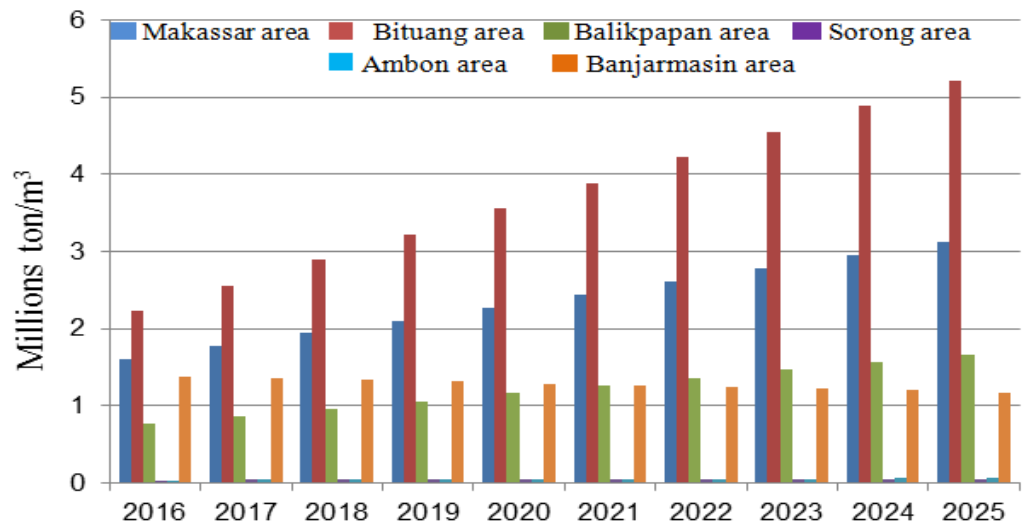

Figure 4. Projection of Demand for General Cargo Services in Hinterland of The Eastern Part of Indonesia

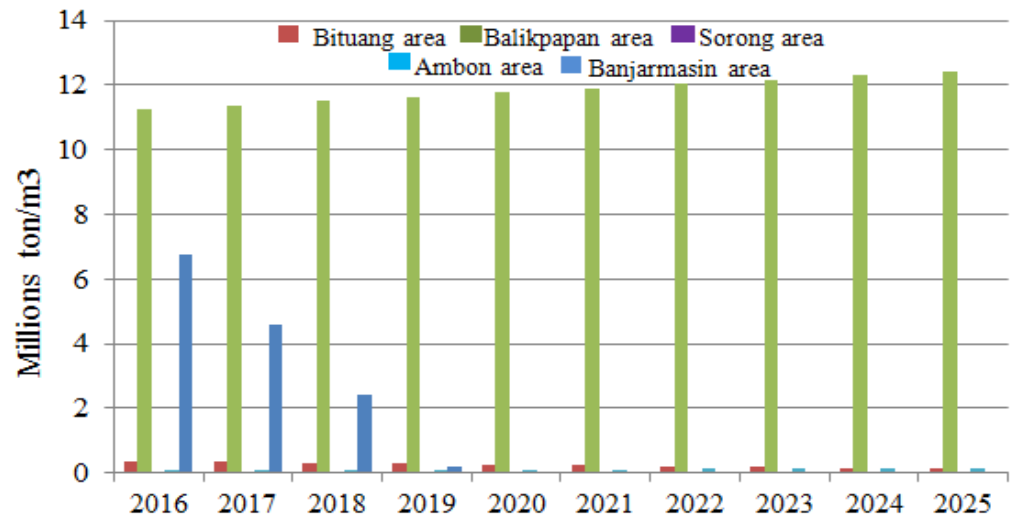

Figure 5. Projection of Demand for Dry Bulk Services in Hinterland of The Eastern Part of Indonesia

The demand for dry bulk transport services in Balikpapan area dominates the one-decade projection due to the significant population growth and geography as a coastal area serving both local and global trade, as shown in Figure 5. The projection is approximately $58.26 \%$ and equivalent to an increase in demand for dry bulk transport services in Makassar area. In contrast, the projection of demand for this service in Banjarmasin area declines until 2019 and vanishes in the subsequent years, caused by the change of packaging trends that tend to shift to container service.

The projection of the demand for passenger transport service is the highest and has a positive trend in Ambon area, as shown in Figure 6. The demand for passenger transport services in Balikpapan, Sorong, and Banjarmasin areas tends to increase as well. In contrast, the demand for this service in Makassar and Bitung areas are small and tend to decrease due to the competition against other modes of transportation. 


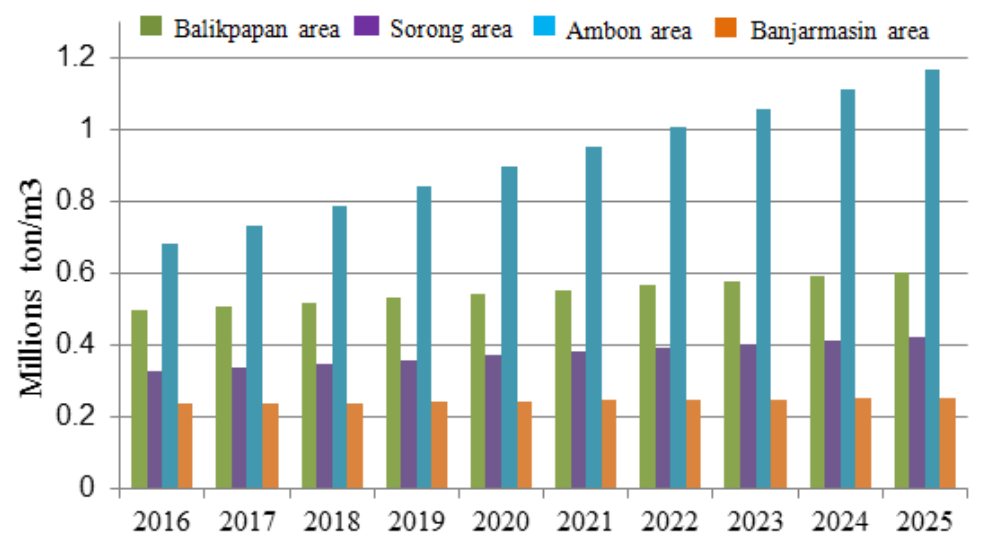

Figure 6. Projection of Demand For Passenger Services In Hinterland of The Eastern Part of Indonesia

The projection of the volume of the ship that serves in the eastern part of Indonesia until 2025 is 6,788,916.05 CGT per year. The details of ship volume by type are provided in Table 5. The most demand is container load and it is about 40,910,605.50 CGT. This situation provides a market opportunity for shipyards to handle various types of medium vessels.

Table 5. The Projection of Ship Volume in The Eastern Part of Indonesia

\begin{tabular}{lllll}
\hline Year & Container (CGT) & General Cargo (CGT) & Dry Bulk (CGT) & Passenger (CGT) \\
\hline 2016 & $3,508,635.10$ & $775,600.96$ & $1,176,198.34$ & $573,064.14$ \\
2017 & $3,644,166.43$ & $822,529.27$ & $1,125,044.28$ & $585,511.51$ \\
2018 & $3,777,110.87$ & $867,996.87$ & $1,072,357.44$ & $602,374.95$ \\
2019 & $3,907,664.77$ & $912,161.99$ & $1,017,960.34$ & $619,008.97$ \\
2020 & $4,035,999.64$ & $955,155.28$ & $1,028,773.65$ & $635,425.66$ \\
2021 & $4,162,266.38$ & $997,086.22$ & $1,046,524.11$ & $651,636.04$ \\
2022 & $4,286,598.66$ & $1,038,047.65$ & $1,064,084.12$ & $667,650.16$ \\
2023 & $4,409,115.62$ & $1,078,119.19$ & $1,081,460.78$ & $683,477.27$ \\
2024 & $4,529,924.02$ & $1,117,369.75$ & $1,098,660.72$ & $699,125.87$ \\
2025 & $4,649,120.01$ & $1,155,859.47$ & $1,115,690.21$ & $714,603.80$ \\
TOTAL & $\mathbf{4 0 , 9 1 0 , 6 0 1 . 5 0}$ & $\mathbf{9 , 7 1 9 , 9 2 6 . 6 4}$ & $\mathbf{1 0 , 8 2 6 , 7 5 4 . 0 0}$ & $\mathbf{6 , 4 3 1 , 8 7 8 . 3 5}$ \\
\hline
\end{tabular}

There were 8 (eight) medium size of the shipbuilding companies that were observed and identified their internal environment factors namely PT. IKI (Persero) - Makassar, PT. Sarana Samudra Pasific Bitung, PT. Pertamina Dok Sorong Papua Barat, PT. Galangan Balikpapan Utama Balikpapan, PT. Dok Kodja Bahari Banjarmasin, PT. IKI Bitung, PT. Steadfast Marine Pontianak, and PT. Dok dan Perkapalan Waiame Ambon. The external environment factors which influence these shipbuilding companies were also identified. The obtained data were analyzed to formulate characteristics of each shipbuilding company. Then, the strategy for improving competitiveness was ordered and formulated systematically based on the value of the obtained strategy criteria and sub-criteria.

\subsection{Criteria and Sub-criteria of Competitiveness Strategy}

To improve the competitiveness of shipyards in the eastern part of Indonesia, criteria, and sub-criteria of the internal and external environment factors that influence competitiveness were identified and then determined. The criteria and subcriteria were identified based on the discussion results with the respondent and the review of some references related to the development strategy of shipyards. As the identification of criteria and sub-criteria, the determined criteria and sub-criteria for the internal and external environment factors shown in Table 6 and Table 7 were modeled by using Analytical Hierarchy Process (AHP) and then these were decomposed hierarchically based on the relationship between criteria and sub-criteria.

\begin{tabular}{|c|c|}
\hline Criteria & Sub-criteria \\
\hline Organization Management & $\begin{array}{l}\text { Responsibility and commitment } \\
\text { Coordination and response } \\
\text { Business network } \\
\text { Manpower with high skill }\end{array}$ \\
\hline Production / Repair Technology & $\begin{array}{l}\text { Facilities } \\
\text { Utilization of the production capacity }\end{array}$ \\
\hline Production / Repair Cost & $\begin{array}{l}\text { Low labor costs } \\
\text { Low cost of material }\end{array}$ \\
\hline Product Performance & $\begin{array}{l}\text { Complex ship types building ability } \\
\text { Delivery time } \\
\text { High quality product }\end{array}$ \\
\hline
\end{tabular}


Table 7. Criteria and Sub-Criteria of The Strategy for External Environment Factors

\begin{tabular}{ll}
\hline Criteria & Sub-criteria \\
\hline Supplier chain & Requisite material and equipment \\
Market Share & Network and partnership with suppliers \\
& Free Market \\
Macro-economic Impact & Increasing domestic demand for shipbuilding and repair \\
& Supporting industries \\
& Logistics and transportation system \\
& Exchange rate \\
Regulation and Policy & Government policies \\
& Bank support \\
& Classification procedures \\
Innovation investment & Human resource development \\
& Delivery and warranty services \\
& Strategic shipyard location \\
Cooperative relationship & Shipping companies' partners \\
& Other shipyards \\
& Subcontractors \\
& Other firms \\
\hline
\end{tabular}

\subsection{Weight of Sub-criteria}

The values of criteria and sub-criteria were collected by using closed-ended questions only with the management level employees of shipbuilding companies, and these were averaged. Then, the reliability values of all the environmental factors were firstly measured by using SPSS. The values of Alpha Cronbach's internal environment and external environment factors were more than 0.60 and 0.70 , respectively. These mean high reliability factors that influence competitiveness. As given, the Alpha Cronbach's analysis of SPSS showed the reliable industry factors to which an acceptable alpha values range of 0.60 0.90 performed moderate and high reliability.

Table 8. The Value Distribution of Internal Environment Factor Based on The Likert Scale

\begin{tabular}{llllll}
\hline Internal Environment & $\begin{array}{l}\text { Strongly } \\
\text { Agree }\end{array}$ & Agree & Neutral & Disagree & $\begin{array}{l}\text { Strongly } \\
\text { disagree }\end{array}$ \\
\cline { 2 - 6 } & $\mathbf{1 . 0 0 0}$ & $\mathbf{0 . 5 1 8}$ & $\mathbf{0 . 2 6 7}$ & $\mathbf{0 . 1 3 5}$ & $\mathbf{0 . 0 6 9}$ \\
\hline Responsibility and commitment & 9 & 8 & 1 & 4 & 0 \\
Coordination and response & 10 & 9 & 3 & 0 & 0 \\
Business network & 3 & 6 & 5 & 4 & 4 \\
Manpower with high skill & 6 & 9 & 6 & 1 & 0 \\
Facilities & 4 & 12 & 4 & 2 & 0 \\
Utilization of the production capacity & 9 & 9 & 2 & 2 & 0 \\
Low labor costs & 0 & 5 & 12 & 4 & 1 \\
Low cost of material & 1 & 8 & 9 & 4 & 0 \\
Complex ship types building ability & 2 & 6 & 8 & 3 & 3 \\
Delivery time & 9 & 4 & 9 & 0 & 0 \\
\hline
\end{tabular}

The weight of sub-criteria as internal and external environment factors was obtained by multiplying the weight of the elements in the weight vector $\mathrm{w}$. Then, the weight distribution of internal and external environment factors based on the five elements of the Likert Scale is shown in Table 8 and Table 9. The weight distribution on each internal and external environment factor tends to three elements of the Likert Scale: strongly agree, agree, and neutral. Although the tendency is on those three elements, the number is slightly different, which means the manager of shipyards considered the internal and external environmental factors as the parameters that influence shipyard competitiveness. Also, the considerations are related to the manager's experiences. Therefore, the weight distribution affects the total weight of the internal and external environment factors that could be considered a priority of the strategy action as discussed accordingly.

Table 9. The Weight Distribution of External Environment Factor Based on The Likert Scale

\begin{tabular}{llllll}
\hline External Environment & $\begin{array}{l}\text { Strongly } \\
\text { Agree }\end{array}$ & Agree & Neutral & Disagree & $\begin{array}{l}\text { Strongly } \\
\text { disagree }\end{array}$ \\
\cline { 2 - 6 } & $\mathbf{1 . 0 0 0}$ & $\mathbf{0 . 5 1 8}$ & $\mathbf{0 . 2 6 7}$ & $\mathbf{0 . 1 3 5}$ & $\mathbf{0 . 0 6 9}$ \\
\hline Requisite material and equipment & 6 & 9 & 5 & 2 & 0 \\
Network and partnership with suppliers & 6 & 13 & 2 & 1 & 0 \\
Free Market & 7 & 5 & 2 & 6 & 2 \\
Increasing domestic demand for shipbuilding and repair & 5 & 10 & 5 & 2 & 0 \\
Supporting industries & 7 & 6 & 7 & 2 & 0 \\
Logistics and transportation system & 6 & 7 & 6 & 3 & 0 \\
Exchange rate & 8 & 6 & 3 & 5 & 0 \\
Government policies & 8 & 7 & 3 & 2 & 2 \\
\hline
\end{tabular}




\begin{tabular}{llllll}
\hline Bank support & 5 & 10 & 3 & 3 & 1 \\
Classification procedures & 4 & 16 & 1 & 1 & 0 \\
Human resource development & 7 & 10 & 3 & 2 & 0 \\
Delivery and warranty services & 2 & 8 & 7 & 2 & 3 \\
Strategic shipyard location & 10 & 10 & 1 & 1 & 0 \\
Shipping industry partners & 13 & 5 & 3 & 1 & 0 \\
Other shipyard partners & 1 & 10 & 7 & 1 & 3 \\
Subcontractor partners & 8 & 8 & 3 & 3 & 0 \\
Other firm partners & 6 & 8 & 5 & 2 & 1 \\
\hline
\end{tabular}

Based on the weight distribution, the total weight of internal environment factors is shown in Table 10. Each shipyard in the eastern part of Indonesia has different problems. However, all respondents recognized the internal environment in which is coordination and response has the highest weight and this means coordination and response has the strongest influence on shipyard competitiveness where its weight is approximately $15.463 \%$.

Similarly, the weight of sub-criteria for the external environment factors was calculated in the same method with the weight of sub-criteria for the internal environment factors. Table 11 shows the weight values of sub-criteria for external environment factors. Based on these weights, the sub-criterion of shipping industry partners has the highest weight of around $16.526 \%$, which means the shipping industry partners have the strongest influence on shipyard competitiveness. In contrast, the lowest weight value is on cooperation between shipyards.

\begin{tabular}{ll} 
Table 10. The Weight Of Sub-Criteria For Internal Environment Factors \\
\cline { 2 - 2 } Internal Environment & Weight (\%) \\
\hline Coordination and response (I.1) & 15.463 \\
Utilization of the production capacity (I.2) & 14.466 \\
Responsibility and commitment (I.3) & 13.951 \\
Delivery time (I.4) & 13.475 \\
Manpower with high skill (I.5) & 12.399 \\
Facilities (I.6) & 11.554 \\
Business network (I.7) & 8.259 \\
Low cost of material (I.8) & 8.087 \\
Complex ship types building ability (I.9) & 7.856 \\
Low labor costs (I.10) & 6.403 \\
High quality product (I.11) & 3.004 \\
\hline
\end{tabular}

Table 11. The Weight Of Sub-Criteria For External Environment Factors

\begin{tabular}{ll}
\hline External Environment & Weight (\%) \\
\hline Requisite material and equipment (E.1) & 12.267 \\
Network and partnership with suppliers (E.2) & 13.403 \\
Free Market (E.3) & 11.072 \\
Increasing domestic demand for shipbuilding and repair (E.4) & 11.785 \\
Supporting industries (E.5) & 12.247 \\
Logistics and transportation system (E.6) & 11.633 \\
Exchange rate (E.7) & 12.584 \\
Government policies (E.8) & 12.835 \\
Bank support (E.9) & 11.455 \\
Classification procedures (E.10) & 12.69 \\
Human resource development (E.11) & 13.251 \\
Delivery and warranty services (E.12) & 8.49 \\
Strategic shipyard location (E.13) & 15.582 \\
Shipping companies' partners (E.14) & 16.526 \\
Other shipyard partners (E.15) & 8.391 \\
Subcontractor partners (E.16) & 13.35 \\
Other firm partners (E.17) & 11.818 \\
\hline
\end{tabular}

\subsection{Reconstruction of Sub-criteria Using BOS Method}

All sub-criteria have relevance with others, as explained previously. However, some sub-criteria have a minor significance in the current situation. Therefore, the weight values of sub-criteria could be reconstructed by using the Eliminate-Reduce-Raise-Create Grid (ERRC Grid) of the Blue Ocean Strategy (BOS) method. In order to reconstruct the value of these sub-criteria, some questions were discussed with respondents. The followings are some explanations regarding reconstruction using the Eliminate-Reduce-Raise-Create Grid (ERRC Grid) of the internal environment factors. In the Eliminate-Grid, most shipowners' consideration for using shipyard services depends on whether the completion of the shipbuilding works on time or early without neglecting the construction quality.

This condition has become a concern for shipowners so that the shipyard can control the completion time appropriately. This problem can be solved by ensuring greater coordination and response. The management organization system of the 
shipyard has to perform coordination and response effectively to meet completion time and quality standards. This also would contribute to high profit for the shipyard.

In this Reduce-Grid scheme, the discussion with respondents concluded that the work system could be improved by planning the production and repair process to utilize production capacity optimally. As consumers, the shipowners expect the performance of shipyard workers to assure the quality of the product. Each worker is empowered on their task function. Therefore, any workers can perform their duties properly. The communication is formed both vertically and horizontally so that positive opinions and improvement ideas could be delivered easily.

In the Raise-Grid scheme, shipbuilding companies' managers agree on the importance of services that are proportional to the product price. Service satisfaction could be in the form of a shipowner as a regular customer. Furthermore, the shipyard could offer a variety of product specifications to customers, including a complex ship structure type. This will increase shipyard competitiveness in the future.

Moreover, in the Create-Grid scheme, engineering detail of ship construction must be supported by design technology. The shipowner has to determine ship specifications, which are technically feasible and operationally safe. This condition can be achieved in the early stages of production and repair work by the design and specifications of a ship. Besides, work safety is also required during the production and repair process. Based on the discussion above, the sub-criteria of the internal environment factors such as responsibility and commitment, low labor costs, low cost of materials, and delivery time were eliminated. In the Reduce-Grid, the displacement of sub-criteria of facilities and utilization of the production capacity was reduced. The displacement of sub-criteria of business network, manpower with high skill, and complex ship types building ability were raised using the Raise-Grid scheme. The sub-criterion of coordination and response was expected high for all respondents to be developed basically in shipyards in the eastern part of Indonesia. The BOS displacement of all sub-criteria for the internal environment factors after reconstruction can be seen in Figure 7.

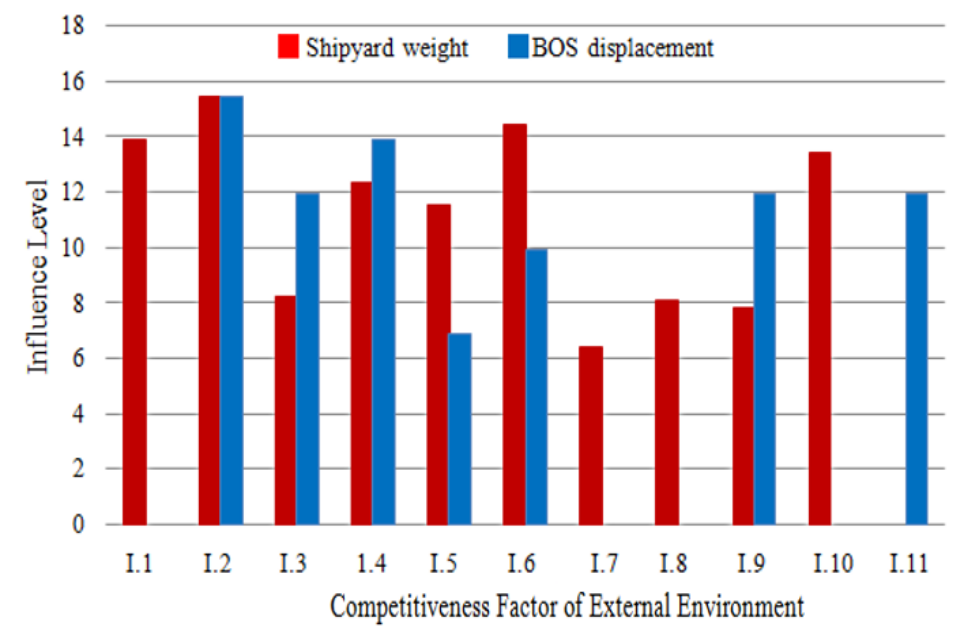

Figure 7. The Influence Level of Internal Environment Factors After Reconstructed Using BOS Method

In addition, the external environment factors were evaluated and reconstructed using a four-step work scheme Eliminate-Reduce-Raise-Create Grid (ERRC Grid) of the Blue Ocean Strategy (BOS) method. Two Archipelagic Sea-Lanes $\left(\mathrm{ASL}^{\prime} \mathrm{s}\right)$ in Indonesia have enabled maritime transit through the eastern part of Indonesia, namely ALKI II and ALKI III. Interestingly, the shipyards' location in the eastern part of Indonesia is passed by ALKI I and ALKI II. These shipyards could take advantage of this opportunity. However, their location is far from material sources and supporting industries. Therefore, shipyards in the stern part of Indonesia need to establish a partnership with other companies to obtain material and other components easily without location constraint.

Some shipyards in the eastern part of Indonesia have made serious efforts to improve competitiveness by reviewing their workers' performance. In fact, high productivity could contribute to high competitiveness. Therefore, shipyard location can be balanced with the high productivity on ship production and ship repair process so that the effect of the shipyard location on competitiveness could be reduced. The high productivity also could satisfy the ship owners because of the fast production process. With high productivity, shipyards will no longer worry even though the ship owners can choose freely where to build and repair their ship. The shipyard must also provide quality assurance and always according to the ship classification standard to retain the shipowners' loyalty. In order to increase productivity, the shipyards should utilize their workers appropriately and focus on fast production processes. Therefore, the shipyards must perform teamwork properly and improve their workers' skills through training or formal education.

Although some shipbuilding companies do not have shares of the international market, the shipyards in the eastern part of Indonesia should utilize as many local market potentials as possible to increase domestic demand for shipbuilding and repair. Therefore, shipping companies must establish a partnership and cooperation with other shipyards and subcontractors in the eastern part of Indonesia.

On the one hand, Indonesia's government regulation and policy are considered as mandatory things that must be implemented to support the nation's economy. However, this policy has not been fully implemented in the current situation. On the other hand, national shipping and shipbuilding industries require some specific policies that could strengthen their business cycle and lead them to improve their competitiveness. 
Based on the above discussion, some sub-criteria for external environment factors could be removed or should not be considered tightly in competitiveness, namely requisite material and equipment, free Market, exchange rate, classification procedures, and delivery and warranty services. The influences of the sub-criteria are derived from business partner strategy and quality assurance. The sub-criteria, including network and partnership with suppliers, increasing domestic demand for shipbuilding and repair, logistics and transportation system, government policies, human resource development, and other shipyard partners, should be improved. These were in line sequentially with the business network improvement strategy and skills of the workers. Moreover, the sub-criteria of logistics and transportation system, bank support, strategic shipyard location, and subcontractor partners could be reduced by shipyards to focus on increasing productivity and ensuring the product quality.

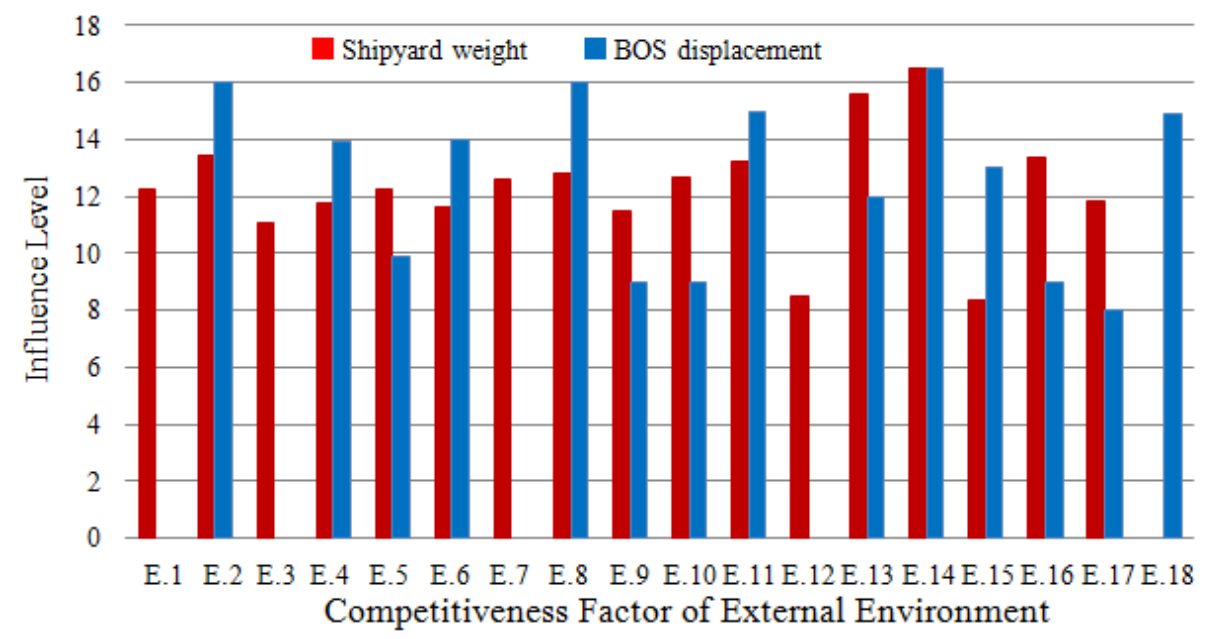

Figure 8. The Influence Level of Internal Environment Factors After Reconstructed Using BOS Method

Furthermore, the formation of clusters of shipyards (E.18) was added as a new sub-criterion in competitiveness strategy by using the BOS method, which could balance the function of sub-criteria that have been reduced and eliminated. The weight of influence for all of the sub-criteria in competitiveness is shown in Figure 8. Five sub-criteria with great influence on improving competitiveness for shipyards in the eastern part of Indonesia were shipping company partners, network and partnership with suppliers, government policies, human resource development, and the formation of clusters of shipyards.

In addition, the weights of external factors, including network and partnership with suppliers, government policies, and shipping company partners, were higher than others. These were external factors that affect most competitiveness, which means that the shipyards in the eastern part of Indonesia should focus on these external factors which lead to an increase of some value-costs.

\section{Conclusion}

The criteria and sub-criteria as the competitiveness factors for the shipyards in the eastern part of Indonesia were identified by the literature review and discussion with the expert people and then decomposed successfully by using AHP. Correspondingly, the value and weight of the criteria and sub-criteria were obtained and then these were reconstructed by using the Eliminate-Reduce-Raise-Create Grid (ERRC Grid) of the Blue Ocean Strategy (BOS) method. Therefore, the strategy for improving the competitiveness of the shipyards in the eastern part of Indonesia was considered accordingly.

There are three sub-criteria of internal environment factors that have higher weight than other factors, namely coordination and response, utilization of the production capacity, and then responsibility and commitment. These factors have a higher weight on competitiveness. Besides, shipping company partners, strategic shipyard location, network, and partnership with suppliers have a higher weight on the external environmental factors. The Blue Ocean Strategy method was then applied to obtain a systematic approach in order to improve competitiveness for shipyards in the eastern part of Indonesia. This could assert that the strategic moves create a leap in value for the company with four actions framework (ERRC Grid).

In the internal environment factors, the displacement of business networks, human resources with high skill, and complex ship types building ability are raised by using the Raise-Grid scheme. The sub-criterion of coordination and response is expected highly by all respondents (shipyard' s managers) to be developed basically in shipyards in the eastern part of Indonesia. In the external environment factors, five factors have strong influence in improving the competitiveness of shipyards in the eastern part of Indonesia namely shipping company partners, network and partnership with suppliers, government policies, human resource development, and the formation of clusters of shipyards.

Future work, the parameters of the internal and external factors that were concluded, will be measured in the western part of Indonesia's shipyards and become a parameter for the shipyards in the eastern part of Indonesia.

\section{Acknowledgements}

We gratefully acknowledge the support from the shipbuilding companies in the eastern part of Indonesia in filling our questionnaire and took their time for discussion. 


\section{References}

[1] C. C. Forward, "Archipelagic Sea-Lanes in Indonesia - Their Legality in International Law," Australian and New Zealand Maritime Law Journal, vol. 23, No. 2, pp. 143-154, 2009.

[2] A. S. Alisjahbana, "Arah Kebijakan dan Strategi Percepatan Pengembangan Kawasan Timur Indonesia," Paper presented at Rapat Koordinasi Bank Indonesia-Pemerintah Pusat dan Daerah, Kementerian Perencanaan Pembangunan Nasional, Manado, 2014.

[3] BAPPENAS, "Brief Perspective on National and International Shipping Network in Indonesia," Paper presented at the Locally Integrated Globally Connected, 23-25 July 2013.

[4] I. R. Tulyakova, E. Gregova and V. V. Dengov, "Assessment of Competitiveness of shipbuilding Industry in Russia," Nase More, vol. 64, No. 3, pp. 112-119, 2017.

[5] L. Jiang and S. Strandenes, "Assessing the Cost Competitiveness of China's Shipbuilding Industry," Maritime Economics and and Logistics, 14, pp. 480-497, 2012.

[6] Y. HE and X. QIAN, "Analysis of the Formation Mechanism of Competitiveness of Shipbuilding Industry in China," International Business and Management, vol. 9, No. 1, pp. 27-34, 2014.

[7] J. S. Lee, "Directions for the Sustainable Development of Korean Small and Medium Sized Shipyards," The Asian Journal of Shipping and Logistics, vol. 29, No. 3, pp. 335-360, 2013.

[8] B. Ma' ruf, "Strategic Analysis of the Indonesian Shipyards to Sustain in New Building Business," International Journal of Management, Business, and Economics, vol. 6, No. 2, pp. 17-31, 2019.

[9] F. O. de Araujo, P. R. T. Dalcol and W. P. e Longo, "A Diagnosis of Brazilian Shipbuilding Industry on the Basis of Methodology for an Analysis of Sectorial Systems of Innovation," Journal of Technology Management and Innovation, vol. 6, Issue 4, pp.151-170, 2011.

[10] K. M. Thangam and D. Sureshkumar, "Competitiveness of Indian Ship Building Industry," International Journal of Innovative Research and Development, vol. 4, Issue 7, pp. 18-25, 2015.

[11] G. Carmen, "The Internal and External Environment Analysis of Romanian Naval Industry with SWOT Model," Management \& Marketing, vol. 4, No. 3, pp. 97-110, 2009.

[12] K. A. Hossain and M. N. G. Zakaria, "SWOT Analysis of China Shipbuilding Industry by Third eyes," Recent Advances in Petrochemical Science, vol. 4, Issue 2, pp. 33-42, 2018.

[13] M. Kafalı and M. Ozkokb, "Evaluation of shipyard selection criteria for shipowners using a fuzzy technique," Journal of Marine Engineering \& Technology, vol. 14, No. 3, pp. 146-158, 2015.

[14] M. K. Othman, N. S. F. A. Rahman and K. Muthoovaloo, "Selection of the Most Challenges Criteria on Malaysian Shipyards Industry Using an Analytic Hierarchy Process Technique," International Journal of e-Navigation and Maritime Economy, 9, pp. 1-14, 2018.

[15] S. L. Chao, "Comparing the Productivity of Major Shipyards in China, South Korea, And Japan - An Application of a Metafrontier Framework," Maritime Business Review, vol. 5, No. 2, pp. 193-210, 2020.

[16] Samri and M. D. T. P. Nasution, "The Formulation of Blue Ocean Strategy for Small and Medium Industry in Tanjung Balai City North Sumatera - Indonesia," International Journal of Economics, Commerce and Management, vol. V, Issue 12, pp. 956-979, 2017.

[17] N. N. K. Yasa, I. G. A. K. Giantari, A. A. S. K. Dewi, A. A. A. Sriathi and K. Ardana, "Role of Blue Ocean Strategy (BOS) Implementation in Improving Performance of and Competitive Advantage of Products (Studies on Smis - Small and Medium-Sized Industries in Bali)," International Journal of Business and Management Invention, vol. 6, Issue 3, pp. 16, 2017.

[18] M. V. Vasiljeva, V. V. Ponkratov, N. V. Kuznetsov, M. S. Maramygin and I. V. Osinovskaya, "Implementation of the Blue Ocean Strategy Using Simulation: Firm-Level Evidence from Russian Steel Market," Industrial Engineering and Management Systems, vol. 18, No.4, pp. 859-871, 2019.

[19] C. Anderson and N. Nardini, "Sailinnovation - Sailing into a Blue Ocean," Master' s Thesis, Linnaeus University, 2010.

[20] T. L. Saaty, "Decision Making with the Analytic Hierarchy Process," International Journal of Services Science, vol. 1 No. 1, pp. 83-98, 2008.

[21] W.C. Kim and R. Mauborgne, "Blue Ocean Strategy: Tools and Frameworks," 2014. 